\title{
V8-Glu Protein Cleavage Reagent
}

National Cancer Institute

\section{Source}

National Cancer Institute. V8-Glu Protein Cleavage Reagent. NCI Thesaurus. Code C161896.

A protein cleavage reagent comprised of the bacterial serine proteinase V8-Glu that cleaves proteins into peptides at the glutamate or glutamine residue unless that residue is followed by a proline. 